\title{
Effects of Propofol on Glutamate-Induced Calcium Mobilization in Presynaptic Boutons of Rat Hippocampal Neurons
}

\author{
Shinichi Ito, Noriko Karube, Hitomi Sugiyama, Jun Hirokawa, Seiko Kitahara, \\ Takeshi Yokoyama \\ Department of Dental Anesthesiology, Faculty of Dental Science, Kyushu University, Fukuoka, Japan \\ Email: ito@dent.kyushu-u.ac.jp
}

Received 19 February 2016; accepted 14 March 2016; published 17 March 2016

Copyright (C) 2016 by authors and Scientific Research Publishing Inc.

This work is licensed under the Creative Commons Attribution International License (CC BY).

http://creativecommons.org/licenses/by/4.0/

(c) (7) Open Access

\begin{abstract}
Recent reports have suggested that various general anesthetics affect presynaptic processes in the central nervous system. However, characterizations of the influence of intravenous anesthetics on neurotransmitter release from presynaptic nerve terminals (boutons) are insufficient. Because the presynaptic calcium concentration $\left(\left[\mathrm{Ca}^{2+}\right]_{\text {pre}}\right)$ regulates neurotransmitter release, we investigate the effects of the intravenous anesthetic propofol on neurotransmitter release by measuring $\left[\mathrm{Ca}^{2+}\right]_{\text {pre }}$ in the presynaptic boutons of individual dissociated hippocampal neurons. Brain slices were prepared from Sprague-Dawley rats (10 - 14 days of age). The hippocampal CA1 area was isolated with a fire-polished glass pipette, which vibrated horizontally to dissociate hippocampal CA1 neurons along with their attached presynaptic boutons. Presynaptic boutons were visualized under a confocal laser scanning microscope after staining with FM1-43 dye, and $\left[\mathrm{Ca}^{2+}\right]_{\text {pre }}$ was measured using fluo-3 AM dye. Glutamate $(3-100 \mu \mathrm{M})$ administration increased $\left[\mathrm{Ca}^{2+}\right]_{\text {pre }}$ in $\mathrm{Ca}^{2+}$ containing external solution in a concentration-dependent manner. Propofol $(3-30 \mu \mathrm{M})$ dosedependently suppressed this glutamate $(30 \mu \mathrm{M})$-induced increase in $\left[\mathrm{Ca}^{2+}\right]$ pre in boutons attached to dendrites, but not to the soma or base of the dendritic tree. The large majority of excitatory synapses on CA1 neurons are located on dendritic spines; therefore, propofol may affect glutamate-induced $\mathrm{Ca}^{2+}$ mobilization in excitatory, but not inhibitory, presynaptic boutons. Propofol may possibly have some effect on glutamate-regulated neurotransmitter release from excitatory presynaptic nerve terminals through inhibiting the increase in $\left[\mathrm{Ca}^{2+}\right]$ pre induced by glutamate.
\end{abstract}

\section{Keywords}

Propofol, Calcium Signaling, Presynaptic Terminals, Hippocampus, Glutamic Acid 


\section{Introduction}

The intravenous anesthetic propofol is frequently used in general anesthesia and intravenous sedation. It is typically thought that propofol mainly affects $\gamma$-aminobutyric acid type A $\left(\mathrm{GABA}_{\mathrm{A}}\right)$ receptors on the postsynaptic membrane of neurons in the central nervous system [1]-[7]. Recently, however, there has been great interest in the effects of propofol on presynaptic events, as several reports have suggested that propofol regulates neurotransmitter release from presynaptic nerve terminals (boutons) [8]-[11]. However, knowledge of the effects of propofol on presynaptic processes remains limited.

Glutamate acts postsynaptically as the main excitatory neurotransmitter in the brain, but is also a regulator of many presynaptic processes [12]-[14]. Presynaptic glutamate ionotropic receptors, e.g. $\alpha$-Amino-3-hydroxy-5methyl-4-isoxazolepropionic acid (AMPA)-, kainite- and N-methyl-D-aspartate (NMDA)-type receptors, are a key component of the neurotransmitter release machinery [12] [14]. In addition, metabotropic glutamate receptors mediate presynaptic processes [15] [16]. However, it is unclear if and how general anesthetics, including propofol, affect glutamate-regulated neurotransmitter release from presynaptic boutons.

The release of neurotransmitters is regulated by the presynaptic $\mathrm{Ca}^{2+}$ concentration ([Ca $\left.{ }^{2+}\right]_{\text {pre}}$ ) [17] [18]. To understand the influence of general anesthetics on presynaptic events, it is therefore necessary to characterize changes in presynaptic $\mathrm{Ca}^{2+}$ dynamics after anesthesia administration. In this study, we investigated the effects of the intravenous anesthetic propofol on glutamate-regulated neurotransmitter release by measuring $\left[\mathrm{Ca}^{2+}\right]_{\mathrm{pre}}$ in the presynaptic boutons of hippocampal neurons.

\section{Materials and Methods}

\subsection{Mechanical Dissociation of Hippocampal CA1 Neurons}

All experiments were performed under the Guidance for Animal Experiments at the Faculty of Dental Science, Kyushu University. Ethical approval for this study (Approval Number A20-125-0) was obtained from Animal Care and Use Committee, Kyushu University, Fukuoka, Japan.

Hippocampal CA1 pyramidal neurons were dissociated from 10 - 14 day-old Sprague-Dawley rats as previously described [8]. Briefly, the brain was quickly cut into slices of $400-\mu m$ thickness using a microslicer (DTK-3000W; Dosaka EM, Kyoto, Japan). The slices were then placed in an incubation solution for $1 \mathrm{~h}$, and saturated with $95 \% \mathrm{O}_{2}$ and $5 \% \mathrm{CO}_{2}$ at room temperature $\left(23^{\circ} \mathrm{C}-27^{\circ} \mathrm{C}\right)$. For disassociation, the slices were placed in a chamber containing standard external solution (500 $\mu \mathrm{l}$, see description below), and the hippocampal CA1 region was contacted with a fire-polished glass pipette. The pipette was mechanically vibrated horizontally for 1 min using a custom-made device, which caused dissociation of pyramidal neurons along with the attached presynaptic boutons [8] [19].

\subsection{Presynaptic Calcium Measurement and Staining with FM 1-43}

The dissociated neurons were incubated in standard external solution containing the acetoxymethyl ester of fluo3 (fluo-3 AM; $10 \mu \mathrm{M}$ ) and Pluronic F-127 (0.01\%) for $30 \mathrm{~min}$ at room temperature. The fluo-3AM-loaded presynaptic boutons that were attached to the rat hippocampal CA1 pyramidal neurons were exposed to the standard external solution containing various concentrations (3, 10, 30 and $100 \mu \mathrm{M})$ of glutamate for $10 \mathrm{~s}$ at room temperature. Images of fluo-3-labeled neurons and their adherent presynaptic boutons were obtained using a confocal laser scanning microscope (IX70; Olympus, Tokyo, Japan). The dye-labeled neurons were excited at $488 \mathrm{~nm}$ by passing an argon laser beam through an objective lens (UPlanApo 40X; Olympus, Tokyo, Japan), and fluo-3 fluorescent green signals were recorded through a 505-525-nm bandpass filter using a scan unit (FVX-SU; Olympus, Tokyo, Japan) at 0.42 s intervals.

After measuring the changes in fluo-3 fluorescence intensity, individual presynaptic boutons were visualized by high $\mathrm{K}^{+}$depolarization in the presence of FM1-43, as follows. A dissociated neuron was exposed to a $60 \mathrm{mM}$ $\mathrm{K}^{+}$-containing standard external solution (prepared by replacing $55 \mathrm{mM} \mathrm{NaCl}$ with equimolar $\mathrm{KCl}$ ) for $30 \mathrm{~s}$ in the presence of $10 \mu \mathrm{M}$ FM1-43 and then washed with a standard external solution for 10 min. The FM1-43 dye was excited with an argon laser, and the emitted green fluorescence signal was recorded using a 560-nm longpass filter. The FM1-43-labeled boutons expressed a pseudo red color that distinguished them from the fluo-3 green signals. The morphology of the hippocampal neurons was clearly visualized in the fluo-3 images, and the cellular regions to which the presynaptic boutons attached were thereby readily distinguished in fluorescent im- 
ages after measurement of fluo-3 and FM1-43 fluorescence, as previously described [8]. In order to estimate $\left[\mathrm{Ca}^{2+}\right]_{\text {pre }}$, the mean intensity $(\mathrm{F})$ of the boutons was calculated, and the data were expressed as the ratio of fluorescence intensity change $\left(\Delta \mathrm{F}=\mathrm{F}-\mathrm{F}_{0}\right)$ relative to the control values before stimulation $\left(\mathrm{F}_{0}\right)$, i.e. $\Delta \mathrm{F} / \mathrm{F}_{0}$. In order to smooth the noise, the peak values of the changes in $\left[\mathrm{Ca}^{2+}\right]_{\text {pre }}$ were calculated as the average of $6-12$ points of the maximum response in each bouton.

In order to elucidate the effects of propofol on the glutamate-induced increase in $\left[\mathrm{Ca}^{2+}\right]_{\text {pre }}$ in presynaptic boutons, propofol $(3-30 \mu \mathrm{M})$ was pretreated for $3 \mathrm{~min}$ in the standard external solution and was present during the application of $30 \mu \mathrm{M}$ glutamate.

\subsection{Solutions}

The incubation solution was saturated with $95 \% \mathrm{O}_{2}+5 \% \mathrm{CO}_{2}$ and contained (in $\mathrm{mM}$ ): $\mathrm{NaCl}$ (125), $\mathrm{KCl}$ (2.5), $\mathrm{CaCl}_{2}$ (2), $\mathrm{MgCl}_{2}$ (2), $\mathrm{NaH}_{2} \mathrm{PO}_{4}$ (1.5), $\mathrm{NaHCO}_{3}$ (26), and glucose (20). The standard external solution (pH 7.4) contained (in $\mathrm{mM}$ ): $\mathrm{NaCl}$ (150), $\mathrm{KCl}$ (5), $\mathrm{CaCl}_{2}$ (2), $\mathrm{MgCl}_{2}$ (1), HEPES (5), and glucose (10). The concentration of $\mathrm{K}^{+}$was modified isosmotically by replacing $\mathrm{NaCl}$ with $\mathrm{KCl}$.

\subsection{Drugs}

The drugs used were L-glutamic acid, dimethyl sulfoxide (DMSO), HEPES, Pluronic F-127 (Sigma-Aldrich, Inc, St. Louis MO, USA), fluo-3 AM (Dojindo Laboratories, Kumamoto, Japan), FM1-43 (Molecular Probes, Inc, Eugene OR, USA), and 2, 6-diisopropylphenol (propofol; Tokyo Chemical Industry Co, Ltd, Tokyo, Japan).

\subsection{Statistics}

Data are presented as mean \pm standard error of mean (SEM). The results were tested with analysis of variance (ANOVA) followed by Dunnett's test. Differences between control and test values were considered significant when $P<0.05$. Analyses were carried out using the Japanese version of KaleidaGraph software (Version 4.5.0; Synergy Software, Reading PA, USA).

\section{Results}

\subsection{Identification of Presynaptic Boutons}

Single presynaptic boutons on a hippocampal CA1 pyramidal neuron were stained with FM1-43 after $\mathrm{Ca}^{2+}$ measurement so that the green fluorescence emitted by FM1-43 would not affect the measurement of fluo-3 fluorescence intensity changes. The FM1-43-labelled presynaptic boutons expressed a pseudo red color that distinguished them from the fluo-3 green fluorescence (Figure 1). To confirm that these FM1-43 labelling spots represented single boutons, a $60 \mathrm{mM} \mathrm{K}^{+}$-containing external solution was applied to the neurons. A red spot that disappeared after high $\mathrm{K}^{+}$stimulation was considered a presynaptic bouton (data not shown) [19]. In order to estimate $\left[\mathrm{Ca}^{2+}\right]_{\text {pre }}$ in a presynaptic bouton, the mean fluo-3 fluorescence intensity of a red spot was calculated.

\subsection{Glutamate-Induced Increases in $\left[\mathrm{Ca}^{2+}\right]$ pre in Presynaptic Boutons}

An external solution containing $2 \mathrm{mM} \mathrm{Ca}^{2+}$ and various concentrations of glutamate ( 3 - $100 \mu \mathrm{M}$ ) was applied to the presynaptic boutons attached to the rat hippocampal CA1 pyramidal neurons for $10 \mathrm{~s}$ at room temperature $\left(23^{\circ} \mathrm{C}-27^{\circ} \mathrm{C}\right)$. First, we found that the application of $30 \mu \mathrm{M}$ glutamate produced a rapid increase in $\left[\mathrm{Ca}^{2+}\right]_{\text {pre }}$ in the $\mathrm{Ca}^{2+}$-containing external solution (Figure 2(a)). Then, we tested the dose response of presynaptic boutons to glutamate $(3-100 \mu \mathrm{M})$ and observed a concentration-dependent increase in $\left[\mathrm{Ca}^{2+}\right]_{\text {pre }}$ (Figure 2(b)). Glutamate $(3-100 \mu \mathrm{M})$ produced an increase in $\left[\mathrm{Ca}^{2+}\right]_{\text {pre }}$ in $72.8 \%$ of the presynaptic boutons attached to the soma and the base of the dendritic tree, while $51.1 \%$ of the boutons attached to dendrites responded to glutamate (Table 1 ).

\subsection{Effects of Propofol on the Glutamate-Induced Increase in $\left[\mathrm{Ca}^{2+}\right]_{\text {pre }}$}

We investigated the effects of propofol on glutamate $(30 \mu \mathrm{M})$-induced presynaptic $\mathrm{Ca}^{2+}$ mobilization in the rat hippocampal CA1 pyramidal neuron. A large majority of excitatory synapses are located on dendritic spines [20] [21]. On the other hand, inhibitory boutons mainly attach to the soma or the base of the dendritic tree [19]. 


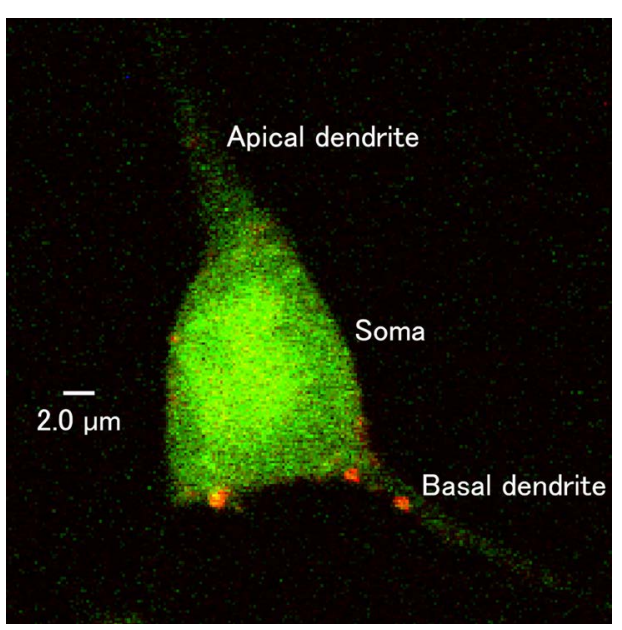

Figure 1. Fluorescence image of a hippocampal CA1 pyramidal neuron. After measurement of changes in fluo-3 fluorescence intensity, a dissociated hippocampal neuron along with the attached presynaptic boutons was exposed to $10 \mu \mathrm{M}$ FM1-43 in a $60 \mathrm{mM} \mathrm{K+-containing} \mathrm{standard} \mathrm{external} \mathrm{solution} \mathrm{for} 30 \mathrm{~s}$. Subsequently, the neuron was washed with the standard solution. The FM1-43-labelled presynaptic boutons expressed a pseudo red color that distinguished them from the fluo-3 green fluorescence.

(a)

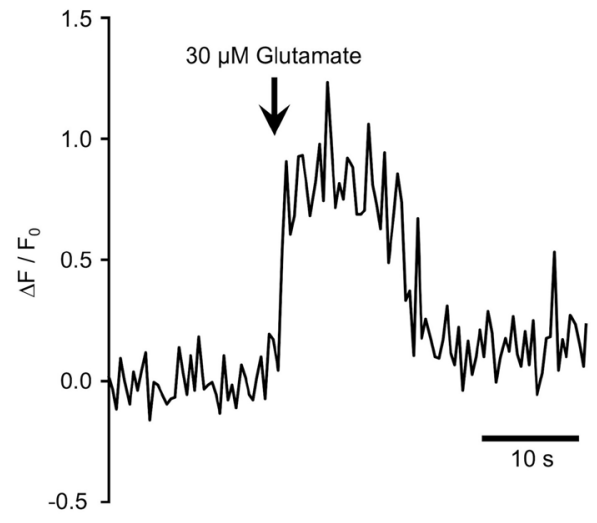

(b)

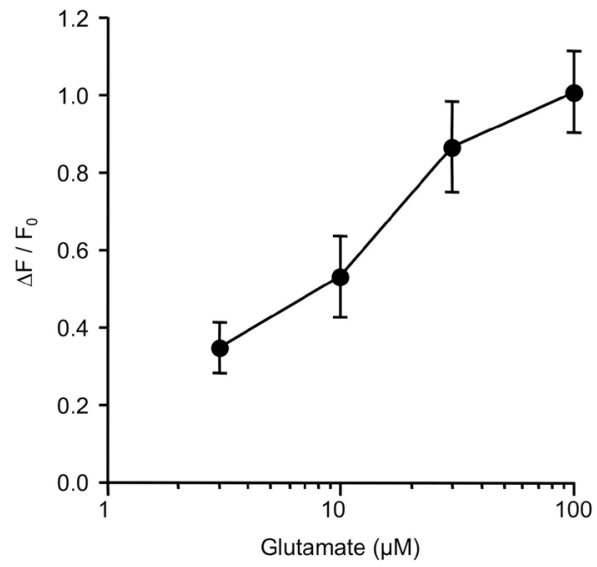

Figure 2. Glutamate induced an increase in $\left[\mathrm{Ca}^{2+}\right]$ pre in the presence of external $\mathrm{Ca}^{2+}$. (a) Representative trace of 20 experiments indicating that $30 \mu \mathrm{M}$ glutamate produced an increase in $\left[\mathrm{Ca}^{2+}\right]_{\text {pre }}$ in rat hippocampal neurons in an external solution containing $2 \mathrm{mM} \mathrm{Ca}^{2+}$. (b) A concentration-response curve indicating a dose dependent glutamate-induced $\left[\mathrm{Ca}^{2+}\right]_{\text {pre }}$ increase in $\mathrm{Ca}^{2+}$-containing solution. The ordinate shows the peak $\left[\mathrm{Ca}^{2+}\right]_{\text {pre }}$ of the response after subtracting the baseline value. The data points indicate mean \pm SEM of $11-20$ boutons from $8-12$ neurons. $\left[\mathrm{Ca}^{2+}\right]_{\text {pre: }}$ : presynaptic $\mathrm{Ca}^{2+}$ concentration.

Table 1. The number and the proportion of boutons that responded to glutamate (3 - $100 \mu \mathrm{M})$.

\begin{tabular}{|c|c|c|c|}
\hline \multirow{2}{*}{ Location of boutons } & \multirow{2}{*}{ Total number of boutons (neurons) } & \multicolumn{2}{|c|}{ Responding boutons (neurons) } \\
\hline & & Number & Proportion (\%) \\
\hline Soma & $170(112)$ & $128(89)$ & 75.3 \\
\hline Base of apical dendrite & $82(71)$ & $59(55)$ & 72.0 \\
\hline Base of basal dendrite & $53(55)$ & $35(31)$ & 66.0 \\
\hline Apical dendrite & $86(44)$ & $54(38)$ & 63.0 \\
\hline Basal dendrite & $51(27)$ & $16(11)$ & 31.4 \\
\hline Total & 442 (309) & $292(224)$ & 66.1 \\
\hline
\end{tabular}


Therefore, the effects of propofol on $\mathrm{Ca}^{2+}$ dynamics in presynaptic boutons vary across different attachment sites.

The glutamate $(30 \mu \mathrm{M})$-induced changes in $\left[\mathrm{Ca}^{2+}\right]_{\text {pre }}$ in the $\mathrm{Ca}^{2+}$-containing external solution were used as controls. Figure 3(a) and Figure 4(a) show the representative traces of controls in the bouton attached to dendrite and soma, respectively. Pretreatment with propofol $(10 \mu \mathrm{M})$ for 3 min inhibited the $30 \mu \mathrm{M}$ glutamate-induced increase in $\left[\mathrm{Ca}^{2+}\right]_{\text {pre }}$ in presynaptic boutons attached to dendrites (Figure 3(b)). However, no inhibitory effect of propofol $(10 \mu \mathrm{M})$ was observed in presynaptic boutons attached to the soma (Figure 4(b)). Moreover, pretreatment with propofol $(3-30 \mu \mathrm{M})$ dose-dependently inhibited the $30 \mu \mathrm{M}$ glutamate-induced increase in $\left[\mathrm{Ca}^{2+}\right]_{\text {pre }}$ in presynaptic boutons attached to dendrites (Figure 5(a)), but not to the soma or base of the dendritic tree (Figure 5(b)).

\section{Discussion}

In this study, we investigated the effects of propofol on the glutamate-induced increase in $\left[\mathrm{Ca}^{2+}\right]_{\text {pre }}$ in the presynaptic boutons of hippocampal CA1 pyramidal neurons. Glutamate $(3-100 \mu \mathrm{M})$ concentration-dependently in

(a)

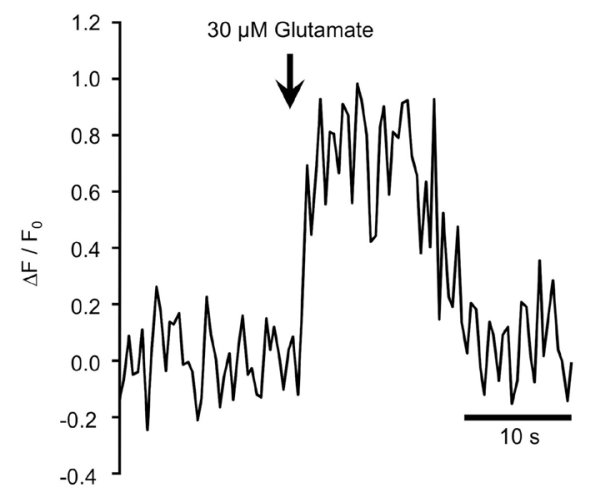

(b)

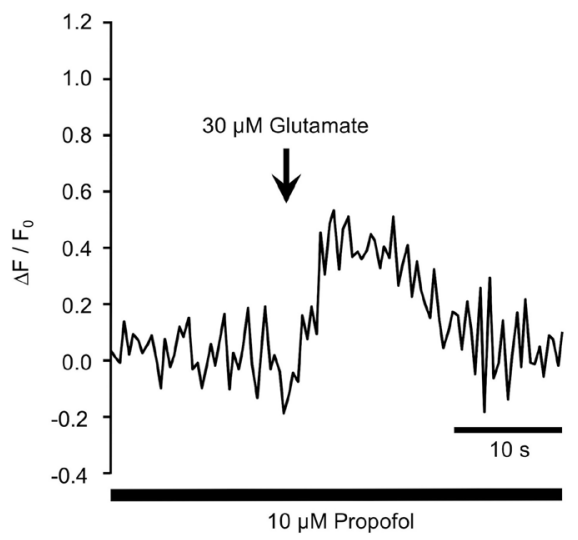

Figure 3. Propofol inhibited the glutamate-induced increase in $\left[\mathrm{Ca}^{2+}\right]_{\text {pre }}$ in boutons attached to dendrites. Glutamate $(30 \mu \mathrm{M})$ was applied for $10 \mathrm{~s}$ in an external solution containing $2 \mathrm{mM} \mathrm{Ca}^{2+}$ and boutons at dendrites were analyzed in (a) control and (b) pretreatment for 3 min with $10 \mu \mathrm{M}$ propofol. The results illustrate $\left[\mathrm{Ca}^{2+}\right]_{\text {pre }}$ in boutons from different dendrites in either condition (a) or (b).

(a)

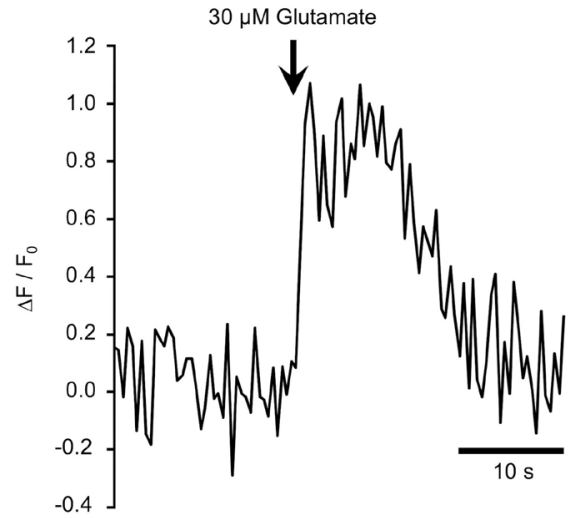

(b)

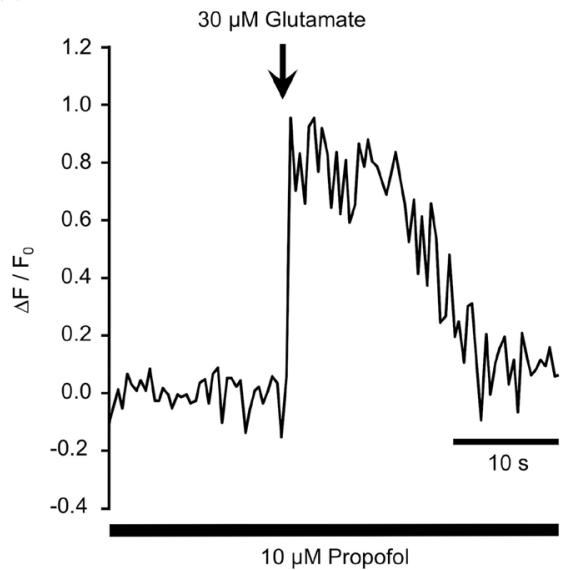

Figure 4. Propofol did not affect glutamate-induced increases in $\left[\mathrm{Ca}^{2+}\right]_{\text {pre }}$ in boutons attached to the soma. Glutamate $(30 \mu \mathrm{M})$ was applied for $10 \mathrm{~s}$ in an external solution containing $2 \mathrm{mM} \mathrm{Ca}^{2+}$ in (a) control and (b) pretreatment for 3 min with $10 \mu \mathrm{M}$ propofol. The results illustrate $\left[\mathrm{Ca}^{2+}\right]_{\text {pre }}$ in boutons from the different soma in either condition (a) or (b). 
(a) Dendrite

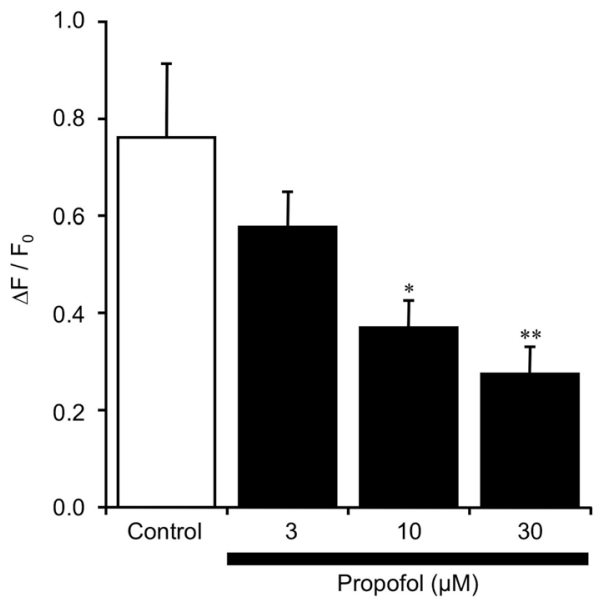

(b) Soma, Base of dendrite

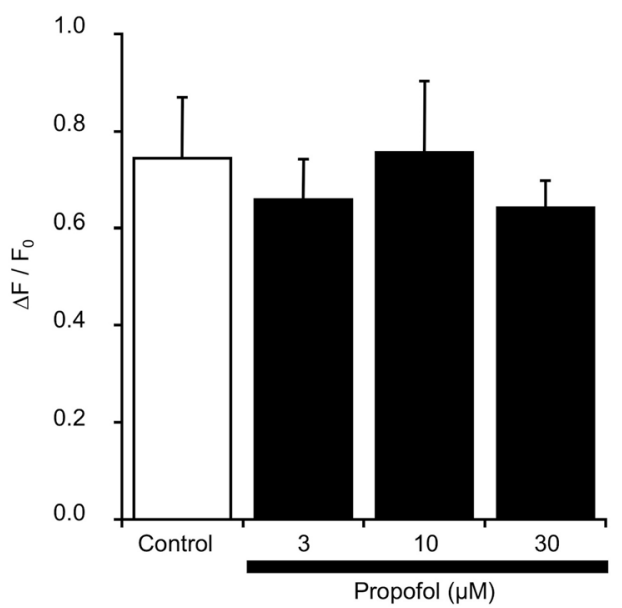

Figure 5. Dose dependent effects of propofol on the $30 \mu \mathrm{M}$ glutamate-induced increase in $\left[\mathrm{Ca}^{2+}\right]_{\text {pre }}$ in dendrites. Each column indicates the average of the peak value of the $30 \mu \mathrm{M}$ glutamate-induced increase in $\left[\mathrm{Ca}^{2+}\right]_{\text {pre }}$ in boutons on either the dendrite or the soma/base of the dendrite. (a) The boutons attached to dendrites were pretreated with propofol at a range of concentrations $(3 \mu \mathrm{M} ; 6$ boutons from 4 neurons, 10 $\mu \mathrm{M}$; 8 boutons from 5 neurons, $30 \mu \mathrm{M}$; 6 boutons from 5 neurons). Pretreatment with propofol $(10-30 \mu \mathrm{M})$ inhibited the $30 \mu \mathrm{M}$ glutamate-induced increase in $\left[\mathrm{Ca}^{2+}\right]_{\text {pre }}$ (control; 8 boutons, 6 neurons) in a concentration-dependent manner. (b) In the boutons attached to the soma or base of dendrite, there was no significant difference between the control (11 boutons from 7 neurons) and pretreatment with propofol groups ( $3 \mu \mathrm{M}$; 6 boutons from 5 neurons, $10 \mu \mathrm{M}$; 6 boutons from 4 neurons, $30 \mu \mathrm{M} ; 6$ boutons from 5 neurons). Data are presented as mean \pm SEM. $* \mathrm{P}<0.05$ and ${ }^{* *} \mathrm{P}<0.01$ represent significant difference from each control, respectively.

creased $\left[\mathrm{Ca}^{2+}\right]_{\text {pre }}$ in neurons/boutons bathed in a $\mathrm{Ca}^{2+}$-containing external solution. Furthermore, propofol (10 $30 \mu \mathrm{M})$ suppressed the glutamate $(30 \mu \mathrm{M})$-induced increase in $\left[\mathrm{Ca}^{2+}\right]_{\text {pre }}$ in the boutons attached to dendrites, but not the boutons attached to the soma or the base of the dendritic tree; this finding is consistent with an effect primarily on excitatory synapses.

Many reports have indicated that increases in $\left[\mathrm{Ca}^{2+}\right]_{\text {pre }}$ are caused by $\mathrm{Ca}^{2+}$ influx via voltage-gated $\mathrm{Ca}^{2+}$ channels, and that a rise in presynaptic $\mathrm{Ca}^{2+}$ triggers the release of neurotransmitters from boutons [17] [18] [22]-[24]. In the present experiments, glutamate $(3-100 \mu \mathrm{M})$ did not increase $\left[\mathrm{Ca}^{2+}\right]_{\text {pre }}$ from all presynaptic boutons. In the boutons attached to dendrites in particular, only about half of them responded to glutamate (Table 1). These findings are likely due to the complex effects of glutamate on the modulation of neurotransmitter release from presynaptic boutons in the hippocampal CA1 region. Glutamate ionotropic receptors on presynaptic boutons participate in neurotransmitter release [12]-[14] [25]-[30], especially in the case of presynaptic kainate receptors that modulate glutamate and GABA release. In the CA1 area, the activation of presynaptic kainate receptors depresses glutamatergic synaptic transmission [25] [27]-[29]. In addition, presynaptic kainate receptors in the hippocampus evidently evoke a metabotropic response that suppresses GABA release at interneuron-CA1 pyramidal cell synapses [30].

AMPA receptor activation tonically facilitates spontaneous GABA release in cultured rat hippocampal neurons [31]. However, there is not sufficient evidence supporting presynaptic AMPA receptor-mediated regulation of $\left[\mathrm{Ca}^{2+}\right]_{\text {pre }}$ mobilization in CA1 pyramidal cells. In the rat hippocampal CA1 area, presynaptic NMDA receptors positively modulate excitatory postsynaptic potentials [32] [33]. Furthermore, presynaptic NMDA autoreceptors were shown to facilitate glutamate release in the rat hippocampus [34]. In this study, however, the external solution did not contained glycine, which is an essential component of NMDA receptor activation [35] [36]; therefore, presynaptic NMDA receptors might not have participated in the glutamate-induced increase in $\left[\mathrm{Ca}^{2+}\right]_{\mathrm{pre}}$ observed in this experiment.

Metabotropic glutamate receptor activation reduces excitatory [15] [37]-[39] and inhibitory synaptic transmission [15] in the hippocampal CA1 region. By contrast, it has been reported that the activation of presynaptic metabotropic glutamate receptors increases glutamate release in CA1 pyramidal cells [16] [40] [41]. It is likely 
that the opposing mechanisms of glutamate-receptor based regulation of neurotransmitter release described

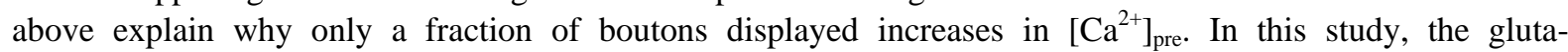
mate-induced changes in fluorescence images were different between presynaptic boutons and postsynaptic neurons (soma and dendrites; data not shown). The glutamate-induced increase in $\left[\mathrm{Ca}^{2+}\right]_{\text {pre }}$ observed in this experiment was the specific response of the boutons via presynaptic glutamate receptors. However, a limitation of this study is that the receptors affected by glutamate and the neurotransmitters released from boutons were not identified. Furthermore, the detailed mechanisms underlying the glutamate-induced increase in $\left[\mathrm{Ca}^{2+}\right]_{\text {pre }}$ were not determined experimentally.

Many reports have suggested that $\left[\mathrm{Ca}^{2+}\right]_{\text {pre }}$ increases are caused by influx of $\mathrm{Ca}^{2+}$ through voltage-gated $\mathrm{Ca}^{2+}$ channels in presynaptic boutons [17] [18] [22]-[24]. We found that the $\mathrm{N}$-type voltage-gated $\mathrm{Ca}^{2+}$ channel blockers $500 \mathrm{nM}$ GVIA and $1 \mu \mathrm{M}$ MVIIA inhibited the glutamate $(30 \mu \mathrm{M})$-induced increase in $\left[\mathrm{Ca}^{2+}\right]_{\text {pre }}$ in $\mathrm{Ca}^{2+}$-containing solution; furthermore, $30-100 \mu \mathrm{M}$ glutamate did not increase $\left[\mathrm{Ca}^{2+}\right]_{\text {pre }}$ in $\mathrm{Ca}^{2+}$-free solution (both data not shown). These findings suggest that the glutamate-induced increase in $\left[\mathrm{Ca}^{2+}\right]_{\text {pre }}$ observed in the $\mathrm{Ca}^{2+}$-containing solution was mainly due to $\mathrm{Ca}^{2+}$ entry through voltage-gated $\mathrm{Ca}^{2+}$ channels.

Presynaptic $\mathrm{GABA}_{\mathrm{A}}$ receptors reduce $\mathrm{Ca}^{2+}$ influx by affecting voltage-gated $\mathrm{Ca}^{2+}$ channels, thereby reducing the release of neurotransmitters [42]. Kitayama et al. have reported that intravenous anesthetics, including propofol, significantly inhibit $\mathrm{K}^{+}$-evoked glutamate release from rat cerebrocortical slices and this inhibition of release is probably due mainly to depression of $\mathrm{P} / \mathrm{Q}$-type voltage-gated $\mathrm{Ca}^{2+}$ channels and partly due to activation of $\mathrm{GABA}_{\mathrm{A}}$ receptors [43]. Buggy et al. have reported that propofol inhibits $\mathrm{K}^{+}$-evoked glutamate release from rat cerebrocortical slices, and propofol inhibition of glutamate release is reversed by the $\mathrm{GABA}_{\mathrm{A}}$ antagonist bicuculline [44]. Furthermore, Wakita et al. have demonstrated that propofol activates both presynaptic and postsynaptic $\mathrm{GABA}_{\mathrm{A}}$ receptors within GABA ergic synapses in rat CA3 neurons [11]. Therefore, propofol may have inhibitory effects on $\mathrm{Ca}^{2+}$ mobilization via presynaptic $\mathrm{GABA}_{\mathrm{A}}$ receptors even in the CA1 area.

In this study, the effects of propofol were established in a concentration of $3-30 \mu \mathrm{M}$. This concentration range of propofol is similar to those of many reports relating to the effects of propofol on neurotransmission [4][7] [11] [44] [45]. The propofol concentration of $3-30 \mu \mathrm{M}$ is equal to $0.534-5.34 \mu \mathrm{g} / \mathrm{ml}$ and seems to correspond with the propofol effect-site concentration in clinical anesthesia. However, propofol is extensively bound to the plasma protein [46], and hence propofol concentration of $10 \mu \mathrm{M}$ or more is considered to be much higher than clinically relevant concentrations of propofol [11] [47]. On the other hand, propofol in a concentration of 2 - $100 \mu \mathrm{M}$ potentiates GABA-activated currents and increases the frequency of opening of GABA channels, while $10-1000 \mu \mathrm{M}$ propofol directly activates $\mathrm{GABA}_{\mathrm{A}}$ channels [1]. In the preparation absent of endogenous GABA, therefore, inhibitory effects of propofol $(\geq 10 \mu \mathrm{M})$ observed in this study probably due to direct activation of presynaptic $\mathrm{GABA}_{\mathrm{A}}$ receptors.

The finding in this study that propofol inhibited glutamate-induced increases in $\left[\mathrm{Ca}^{2+}\right]_{\text {pre }}$ in boutons attached to the dendrite and not in boutons attached to the soma or the base of dendrite provides insight into the mechanism of propofol action. Almost every excitatory bouton attaches to dendritic spines [20] [21], while most inhibitory boutons are located on the soma or the base of the dendritic tree [19]. Therefore, propofol may have an inhibitory effect on glutamate-induced $\mathrm{Ca}^{2+}$ mobilization in excitatory presynaptic boutons, but not in inhibitory boutons. We have previously reported that propofol and pentobarbital inhibit the high $\mathrm{K}^{+}$-induced increase in $\left[\mathrm{Ca}^{2+}\right]_{\text {pre }}$ in the presynaptic boutons attached to dendrite, that is, excitatory synaptic transmission by depolarization [8]. Presynaptic kainate receptors in the rat hippocampal CA3 area directly modulate $\left[\mathrm{Ca}^{2+}\right]_{\text {pre }}$ and induce the exocytotic release of glutamate, contributing to the generation of a positive feedback mechanism responsible for glutamate-induced glutamate release [48]. In excitatory presynaptic boutons in the CA1 area, glutamate-induced increase in $\left[\mathrm{Ca}^{2+}\right]_{\text {pre }}$ via some kind of presynaptic glutamate receptors is similarly considered to provide the positive feedback mechanisms on glutamate-induced neurotransmitter release. Therefore, the significance of this study is the finding of inhibitory effects of propofol on the positive feedback mechanisms by glutamate.

\section{Conclusion}

In conclusion, propofol may possibly have some effect on glutamate-regulated neurotransmitter release from excitatory presynaptic nerve terminals through inhibiting the increase in $\left[\mathrm{Ca}^{2+}\right]_{\text {pre }}$ induced by glutamate.

\section{Acknowledgements}

This work was supported by Japan Society for the Promotion of Science (JSPS) Grant-in-Aid for Scientific Re- 
search (21592578, 24593058).

\section{Competing Interest}

The authors have no conflict of interest to declare.

\section{Authors' Contributions}

SI participated in the study design, performed the animal experiments, and drafted the manuscript; NK, TY participated in the study design and facilitated drafting of the manuscript; HS, SK participated in the animal experiments and facilitated drafting of the manuscript; JH performed statistical analysis and facilitated drafting of the manuscript. All of the authors have read and approved the final manuscript.

\section{References}

[1] Orser, B.A., Wang, L.Y., Pennefather, P.S. and MacDonald, J.F. (1994) Propofol Modulates Activation and Desensitization of $\mathrm{GABA}_{\mathrm{A}}$ Receptors in Cultured Murine Hippocampal Neurons. The Journal of Neuroscience, 14, 7747-7760.

[2] Mantz, J., Lecharny, J.B., Laudenbach, V., Henzel, D., Peytavin, G. and Desmonts, J.M. (1995) Anesthetics Affect the Uptake but Not the Depolarization-EvokedRelease of GABA in Rat Striatal Synaptosomes. Anesthesiology, 82, 502511. http://dx.doi.org/10.1097/00000542-199502000-00020

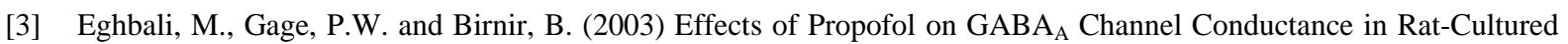
Hippocampal Neurons. European Journal of Pharmacology, 468, 75-82. http://dx.doi.org/10.1016/S0014-2999(03)01641-8

[4] Kitamura, A., Sato, R., Marszalec, W., Yeh, J.Z., Ogawa, R. and Narahashi, T. (2004) Halothane and Propofol Modulation of $\gamma$-Aminobutyric Acid ${ }_{\mathrm{A}}$ Receptor Single-Channel Currents. Anesthesia \& Analgesia, 99, 409-415. http://dx.doi.org/10.1213/01.ANE.0000131969.46439.71

[5] McDougall, S.J., Bailey, T.W., Mendelowitz, D. and Andresen, M.C. (2008) Propofol Enhances Both Tonic and Phasic Inhibitory Currents in Second-Order Neurons of the Solitary Tract Nucleus (NTS). Neuropharmacology, 54, 552-563. http://dx.doi.org/10.1016/j.neuropharm.2007.11.001

[6] Frenkel, C. and Urban, B.W. (1991) Human Brain Sodium Channels as One of the Molecular Target Sites for the New Intravenous Anaesthetic Propofol (2,6-Diisopropylphenol). European Journal of Pharmacology, 208, 75-79. http://dx.doi.org/10.1016/0922-4106(91)90054-L

[7] Jones, P.J., Wang, Y., Smith, M.D., Hargus, N.J., Eidam, H.S., White, H.S., Kapur, J., Brown, M.L. and Patel, M.K. (2007) Hydroxyamide Analogs of Propofol Exhibit State-Dependent Block of Sodium Channels in Hippocampal Neurons: Implications for Anticonvulsant Activity. Journal of Pharmacology and Experimental Therapeutics, 320, 828836. http://dx.doi.org/10.1124/jpet.106.111542

[8] Ito, S., Sugiyama, H., Kitahara, S., Ikemoto, Y. and Yokoyama, T. (2011) Effects of Propofol and Pentobarbital on Calcium Concentration in Presynaptic Boutons on a Rat Hippocampal Neuron. Journal of Anesthesia, 25, 727-733. http://dx.doi.org/10.1007/s00540-011-1186-4

[9] Herring, B.E., McMillan, K., Carolyn, M., Pike, C.M., Marks, J., Aaron, P., Fox, A.P. and Xie, Z. (2011) Etomidate and Propofol Inhibit the Neurotransmitter Release Machinery at Different Sites. The Journal of Physiology, 589, 11031115. http://dx.doi.org/10.1113/jphysiol.2010.200964

[10] Xie, Z., McMillan, K., Pike, C.M., Cahill, A.L., Herring, B.E., Wang, Q. and Fox, A.P. (2013) Interaction of Anesthetics with Neurotransmitter Release Machinery Proteins. Journal of Neurophysiology, 109, 758-767. http://dx.doi.org/10.1152/jn.00666.2012

[11] Wakita, M., Kotani, N., Nonaka, K., Shin, M. and Akaike, N. (2013) Effects of Propofol on GABAergic and Glutamatergic Transmission in Isolated Hippocampal Single Nerve-Synapse Preparations. European Journal of Pharmacology, 718, 63-73. http://dx.doi.org/10.1016/j.ejphar.2013.09.018

[12] Bardoni, R. (2013) Role of Presynaptic Glutamate Receptors in Pain Transmission at the Spinal Cord Level. Current Neuropharmacology, 11, 477-483. http://dx.doi.org/10.2174/1570159X11311050002

[13] Brasier, D.J. and Feldman, D.E. (2008) Synapse-Specific Expression of Functional Presynaptic NMDA Receptors in Rat Somatosensory Cortex. The Journal of Neuroscience, 28, 2199-2211. http://dx.doi.org/10.1523/JNEUROSCI.3915-07.2008

[14] Rodríguez-Moreno, A. and Sihra, T.S. (2013) Presynaptic Kainate Receptor-Mediated Facilitation of Glutamate Release Involves $\mathrm{Ca}^{2+}$-Calmodulin and PKA in Cerebrocortical Synaptosomes. FEBS Letters, 587, 788-792. http://dx.doi.org/10.1016/j.febslet.2013.01.071 
[15] Gereau, R.W. and Conn, P.J. (1995) Multiple Presynaptic Metabotropic Glutamate Receptors Modulate Excitatory and Inhibitory Synaptic Transmission in Hippocampal Area CA1. The Journal of Neuroscience, 15, 6879-6889.

[16] Pinheiro, P.S. and Mulle, C. (2008) Presynaptic Glutamate Receptors: Physiological Functions and Mechanisms of Action. Nature Reviews Neuroscience, 9, 423-436. http://dx.doi.org/10.1038/nrn2379

[17] Schneggenburger, R. and Nehr, E. (2005) Presynaptic Calcium and Control of Vesicle Fusion. Current Opinion in Neurobiology, 15, 266-274. http://dx.doi.org/10.1016/j.conb.2005.05.006

[18] Llinás, R., Sugimori, M. and Silver, R.B. (1992) Presynaptic Calcium Concentration Microdomains and Transmitter Release. Journal of Physiology-Paris, 86, 135-138. http://dx.doi.org/10.1016/S0928-4257(05)80018-X

[19] Akaike, N., Murakami, N., Katsurabayashi, S., Jin, Y.H. and Imazawa, T. (2002) Focal Stimulation of Single GABAergic Presynaptic Boutons on the Rat Hippocampal Neuron. Neuroscience Research, 42, 187-195. http://dx.doi.org/10.1016/S0168-0102(01)00320-0

[20] Leuner, B., Falduto, J. and Shors, T.J. (2003) Associative Memory Formation Increases the Observation of Dendritic Spines in the Hippocampus. The Journal of Neuroscience, 23, 659-665.

[21] Harris, K.M. and Kater, S.B. (1994) Dendritic Spines: Cellular Specializations Imparting Both Stability and Flexibility to Synaptic Function. Annual Review of Neuroscience, 17, 341-371. http://dx.doi.org/10.1146/annurev.ne.17.030194.002013

[22] Takahashi, T. and Momiyama, A. (1993) Different Types of Calcium Channels Mediate Central Synaptic Transmission. Nature, 366, 156-158. http://dx.doi.org/10.1038/366156a0

[23] Kim, D.K. and Catterall, W.A. (1997) $\mathrm{Ca}^{2+}$-Dependent and -Independent Interactions of the Isoforms of the $\alpha_{1 \mathrm{~A}}$ Subunit of Brain $\mathrm{Ca}^{2+}$ Channels with Presynaptic SNARE Proteins. Proceedings of the National Academy of Sciences of the United States of America, 94, 14782-14786. http://dx.doi.org/10.1073/pnas.94.26.14782

[24] Robataille, R., Adler, E.M. and Charlton, M.P. (1990) Strategic Location of Calcium Channels at Transmitter Release Sites of Frog Neuromuscular Synapses. Neuron, 5, 773-779. http://dx.doi.org/10.1016/0896-6273(90)90336-E

[25] Rodríguez-Moreno, A. and Sihra, T.S. (2011) Metabotropic Actions of Kainate Receptors in the Control of Glutamate Release in the Hippocampus. Advances in Experimental Medicine and Biology, 717, 39-48. http://dx.doi.org/10.1007/978-1-4419-9557-5 4

[26] Kullmann, D.M. (2001) Presynaptic Kainate Receptors in the Hippocampus: Slowly Emerging from Obscurity. Neuron, 32, 561-564. http://dx.doi.org/10.1016/S0896-6273(01)00507-4

[27] Vesikansa, A., Sallert, M., Taira, T. and Lauri, S.E. (2007) Activation of Kainate Receptors Controls the Number of Functional Glutamatergic Synapses in the Area CA1 of Rat Hippocampus. The Journal of Physiology, 583, 145-157. http://dx.doi.org/10.1113/jphysiol.2007.133975

[28] Chittajallu, R., Vignes, M., Dev, K.K., Barnes, J.M., Collingridge, G.L. and Henley J.M. (1996) Regulation of Glutamate Release by Presynaptic Kainate Receptors in the Hippocampus. Nature, 379, 78-81. http://dx.doi.org/10.1038/379078a0

[29] Clarke, V.R.J. and Collingridge, G.L. (2002) Characterisation of the Effects of ATPA, a GLU $\mathrm{K}_{5}$ Receptor Selective Agonist, on Excitatory Synaptic Transmission in Area CA1 of Rat Hippocampal Slices. Neuropharmacology, 42, 889902. http://dx.doi.org/10.1016/S0028-3908(02)00039-4

[30] Sihra, T.S. and Rodríguez-Moreno, A. (2011) Metabotropic Actions of Kainate Receptors in the Control of GABA Release. Advances in Experimental Medicine and Biology, 717, 1-10. http://dx.doi.org/10.1007/978-1-4419-9557-5_1

[31] Vignes, M. (2001) Regulation of Spontaneous Inhibitory Synaptic Transmission by Endogenous Glutamate via NonNMDA Receptors in Cultured Rat Hippocampal Neurons. Neuropharmacology, 40, 737-748. http://dx.doi.org/10.1016/S0028-3908(00)00213-6

[32] Suarez, L.M., Suarez, F., del Olmo, N., Ruiz, M., Gonzalez-Escalada, J.R. and Soli, J.M. (2005) Presynaptic NMDA Autoreceptors Facilitate Axon Excitability: A New Molecular Target for the Anticonvulsant Gabapentin. European Journal of Neuroscience, 21, 197-209. http://dx.doi.org/10.1111/j.1460-9568.2004.03832.x

[33] Suarez, L.M. and Solis, J.M. (2006) Taurine Potentiates Presynaptic NMDA Receptors in Hippocampal Schaffer Collateral Axons. European Journal of Neuroscience, 24, 405-418. http://dx.doi.org/10.1111/j.1460-9568.2006.04911.x

[34] Breukel, A.I.M., Besselsen, E., da Silva, F.H.L. and Ghijsen, W.E.J.M. (1998) A Presynaptic N-Methyl-D-Aspartate Autoreceptor in Rat Hippocampus Modulating Amino Acid Release from a Cytoplasmic Pool. The European Journal of Neuroscience, 10, 106-114. http://dx.doi.org/10.1046/j.1460-9568.1998.00008.x

[35] Johnson, J.W. and Ascher, P. (1987) Glycine Potentiates the NMDA Response in Cultured Mouse Brain Neurons. Nature, 325, 529-531. http://dx.doi.org/10.1038/325529a0

[36] Martina, M., Gorfinkel, Y., Halman, S., Lowe, J.A., Periyalwar, P., Schmidt, C.J. and Bergeron, R. (2004) Glycine Transporter Type 1 Blockade Changes NMDA Receptor-Mediated Responses and LTP in Hippocampal CA1 Pyramid- 
al Cells by Altering Extracellular Glycine Levels. The Journal of Physiology, 557, 489-500. http://dx.doi.org/10.1113/jphysiol.2004.063321

[37] Mannaioni, G., Marino, M.J., Valenti, O., Traynelis, S.F. and Conn, P.J. (2001) Metabotropic Glutamate Receptors 1 and 5 Differentially Regulate CA1 Pyramidal Cell Function. The Journal of Neuroscience, 21, 5925-5934.

[38] Faas, G.C., Adwanikar, H., Gereau 4th, R.W. and Saggau, P. (2002) Modulation of Presynaptic Calcium Transients by Metabotropic Glutamate Receptor Activation: A Differential Role in Acute Depression of Synaptic Transmission and Long-Term Depression. The Journal of Neuroscience, 22, 6885-6890.

[39] Capogna, M. (2004) Distinct Properties of Presynaptic Group II and III Metabotropic Glutamate Receptor-Mediated Inhibition of Perforant Pathway-CA1 EPSCs. The European Journal of Neuroscience, 19, 2847-2858. http://dx.doi.org/10.1111/j.1460-9568.2004.03378.x

[40] Fiacco, T.A. and McCarthy, K.D. (2004) Intracellular Astrocyte Calcium Waves in Situ Increase the Frequency of Spontaneous AMPA Receptor Currents in CA1 Pyramidal Neurons. The Journal of Neuroscience, 24, 722-732. http://dx.doi.org/10.1523/JNEUROSCI.2859-03.2004

[41] Perea, G. and Araque, A. (2007) Astrocytes Potentiate Transmitter Release at Single Hippocampal Synapses. Science, 317, 1083-1086. http://dx.doi.org/10.1126/science.1144640

[42] Fischer, Y. and Parnas, I. (1996) Differential Activation of Two Distinct Mechanisms for Presynaptic Inhibition by a Single Inhibitory Axon. Journal of Neurophysiology, 76, 3807-3816.

[43] Kitayama, M., Hirota, K., Kudo, M., Kudo, T., Ishihara, H. and Matsuki, A. (2002) Inhibitory Effects of Intravenous Anaesthetic Agents on $\mathrm{K}^{+}$-Evoked Glutamate Release from Rat Cerebrocortical Slices. Involvement of Voltage-Sensitive $\mathrm{Ca}^{2+}$ Channels and GABAA Receptors. Naunyn-Schmiedeberg's Archives of Pharmacology, 366, 246-253. http://dx.doi.org/10.1007/s00210-002-0590-6

[44] Buggy, D.J., Nicol, B., Rowbotham, D.J. and Lambert, D.G. (2000) Effects of Intravenous Anesthetic Agents on Glu-

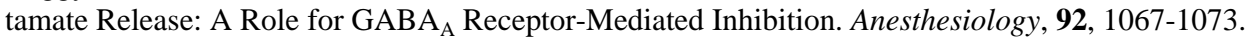
http://dx.doi.org/10.1097/00000542-200004000-00025

[45] Wakita, M., Kotani, N. and Akaike, N. (2016) Effects of Propofol on Glycinergic Neurotransmission in a Single Spinal Nerve Synapse Preparation. Brain Research, 1631, 147-156. http://dx.doi.org/10.1016/j.brainres.2015.11.030

[46] Servin, F., Desmonts, J.M., Haberer, J.P., Cockshott, I.D., Plummer, G.F. and Farinotti, R. (1988) Pharmacokinetics and Protein Binding of Propofol in Patients with Cirrhosis. Anesthesiology, 69, 887-891. http://dx.doi.org/10.1097/00000542-198812000-00014

[47] Kinoshita, H. and Matsuda, N. (2011) Issues Regarding Propofol Concentrations within the Clinical Range. Anesthesiology, 114, 218. http://dx.doi.org/10.1097/ALN.0b013e3181ff728d

[48] Malva, J.O., Silva, A.P. and Cunha, R.A. (2003) Presynaptic Modulation Controlling Neuronal Excitability and Epileptogenesis: Role of Kainate, Adenosine and Neuropeptide Y Receptors. Neurochemical Research, 28, 1501-1515. http://dx.doi.org/10.1023/A:1025618324593

\section{List of Abbreviations}

$\left[\mathrm{Ca}^{2+}\right]_{\text {pre }}$ : presynaptic calcium concentration; fluo-3 AM: acetoxymethyl ester of fluo-3; GABA: $\gamma$-aminobutyric acid; AMPA: $\alpha$-Amino-3-hydroxy-5-methyl-4-isoxazolepropionic acid; NMDA: N-methyl-D-aspartate. 